\title{
Basic Motion Learning Models Based on Traditional Sport Games for Children 10-12 Years Old
}

\author{
$1^{\text {st }}$ Abdul Hakim Siregar ${ }^{1}, 2^{\text {nd }}$ Fajar Sidik Siregar ${ }^{2}$ \\ \{abdhakim@unimed.ac.id ${ }^{1}$, fajar.sidik@unimed.ac.id $\left.{ }^{2}\right\}$ \\ Health and Recreation Physical Education Study Program, Faculty of Sports Science, Universitas \\ Negeri Medan, Indonesia ${ }^{1}$, Elementary School Teacher Education Study Program, Faculty of Science \\ Education, Universitas Negeri Medan, Indonesia ${ }^{2}$
}

\begin{abstract}
This study aims to produce products and test the effectiveness of basic motion learning models based on traditional sports games for children aged 10-12 years. This research and development method uses Research and Development (R\&D) which adopts the Borg \& Gall theory by using 10 rare stages of development. Collecting data using observation, questionnaires, interviews and tests. The data analysis technique used was descriptive qualitative and quantitative. The model effectiveness test used is True Experimental Design research design in the form of a Pretest-Postest Control Group Design with the t-test procedure using the IBM SPSS 25 application. The results showed a significance value for the experimental group data of 0.058 and the control group data of 0.092 because the sig value of the two groups was greater than \&\#945- (0.05), it can be concluded that the overall data of the research group was normally distributed. The effectiveness test of the basic motion learning model using the t-test with the Equal variances assumed column value and the Levene^s Test for Equality of Variances obtained a value of $F=0.030$ with a sig or $p$-value $=0.864>0.05$, which means the population variance of the two groups is the same or homogeneous then the results of the hypothesis test in the Equal variances assumed and t-test for Equality of Means column obtained the value of $\mathrm{t}=17.877, \mathrm{df}=58(\mathrm{n}-2)$ and sig ( 2 tailed) or $\mathrm{p}$-value $=0.000<0.05$ or $\mathrm{H} 0$ is rejected. It can be concluded that the basic motion learning model based on traditional sports games can be effectively accepted for children aged 10-12 years based on expert validation, field tests (small group trials and large group trials) and basic motion learning outcomes of the experimental group using traditional sports game models. more effective than the control group using the conventional model in children aged 10-12 years based on effectiveness testing.
\end{abstract}

Keywords: Basic Movement, Learning Outcomes, Traditional Sports Games.

\section{Introduction}

Education in elementary schools is an institution that is managed and regulated by the government and lasts for 6 years. The purpose of Basic Education is none other than so that Indonesian children become individuals who have been mandated or who have aspired to in the 1945 Constitution. The Graduate Competency Standards for Basic Education itself is to lay the foundation for intelligence, knowledge, personality, noble character and skills. to live independently and pursue further education. Elementary school subjects based on the 2013 curriculum structure consist of general subjects group A and general subjects group B. Group A subjects are curricular programs that aim to develop attitude competence, knowledge 
competence, and competency skills of students as the basis for strengthening abilities in the life of society, nation and state. Subjects that include group A are Religious and Moral Education, Pancasila and Citizenship Education, Indonesian Language, Mathematics, Natural Sciences and Social Sciences. The general subject of group B is a curricular program that aims to develop the competence of attitudes, competence of knowledge, and competence of students' skills related to the environment in the social, cultural and artistic fields. Subjects for the group include Cultural Arts and Crafts and Physical Education, Sports, and Health. In the development of subject matter for group A, which is a group of subjects whose content and references are developed by the center. Whereas, based on the explanation above, the researcher focused on special research on Physical Education, Sports, and Health subjects according to the research field.

Physical education, sports and health are one of the subjects in elementary school. Elementary school is a basic formal education institution that prepares every student to be able to take or follow a higher level of formal education. Formal education is education that is held based on the unit level curriculum for each subject. Each subject has content standards that contain core competencies and basic competencies as general and specific learning objectives to be achieved through the classroom learning process.

The implementation of physical education, sports and health is different and more unique from other forms of education, because the learning is carried out through physical activity. However, in this case, there are still many people who are misguided about physical education. Because this education uses motion or physical activity as a learning tool, it is considered that this education is only a complement because it is intended for the body only, while it is clear that students are human beings who do not consist of disaggregated parts, but are an integrated unit of various parts. , so that the implementation of physical education, sports and health is for students as whole human beings in achieving educational goals.

In the learning process of physical education, sports and health, the teacher plays a role in the implementation of the learning process. Teachers must pay attention to many things regarding students in learning physical education, sports and health such as aspects of child growth and development, and psychological characteristics of children. As described in the 2013 Curriculum that physical education, sports and health are media to encourage physical growth, psychological development, motor skills, knowledge and reasoning, appreciation of values (mental-emotional-sportivity-spiritual-social attitude), and habituation a healthy lifestyle that leads to stimulating growth and development of a balanced physical and psychological quality. Therefore, the subject matter, learning methods,

Institution Education is a planned place that is believed to be able to prepare students who have character with the efforts of all components to develop the potential of students. There are eighteen characters that are expected to be possessed by students as expressed in the training book and development of national character culture education published by the Ministry of Education, namely religious, honest, tolerant, disciplined, hard work, creative, independent, democratic, curiosity, enthusiasm. nationality, love for the homeland, appreciate achievements, friendly/communicative, love peace, love to read, care for the environment, care about social and responsibility. In terms of instilling character values in elementary schools, new innovations are needed that are contained in learning tools ranging from lesson plans, teaching materials, media,

Specifically in the subjects of physical education, sports and health, the researchers conducted a needs analysis by interviewing teachers in the field of sports studies at UPT SD Negeri 064970, SD Negeri 060911, SD Negeri 066054, SD Negeri 067980, SD Negeri 064978 Medan Denai. The results of the interview concluded that sports teachers always try to present 
learning well, by developing physical education, sports and health programs according to the curriculum and implementing learning based on lesson plans. In addition, teachers are also in the learning process of physical education, sports and health, and help students move more purposefully in a small space of movement.

Based on observations made by researchers in the implementation of Physical Education, Sports and Health learning by applying the learning model, there are still shortcomings and improvements are needed, especially in learning basic movements (locomotor, non-locomotor and manipulative). such as learning materials to be provided, time allocation, and good class management. Very real impacts can be seen, among others: (1) lack of teacher approach to students in the learning process, (2) lack of evaluation of learning outcomes for students at the end of the activity, (3) lack of clear targets to be achieved in the learning process (4) lack of understanding teacher in the method or approach that will be used in the delivery of learning materials.

In order to overcome the problems above, there is only one right way to apply, namely increasing the physical activity of elementary school students by developing a model based on observations, interviews and needs analysis conducted by researchers by making products and testing the effectiveness of the basic motion learning model (locomotor, non locomotor and manipulative) based on traditional sports games in children aged 10-12 years in elementary school. The development of the model was developed to improve the deficiencies in the learning process of Physical Education, Sports and Health, especially the basic movement learning materials (locomotor, non-locomotor and manipulative) as a learning model that is accepted and used according to the growth and development level of elementary school students.

Associated with the product that will be developed, the researcher refers to the previous explanation about character education that can be instilled through physical education and sports. Sport as a means to teach physical, spiritual, social, and at the same time as a school of life. Physical Education, Sports and Health are expected to contribute in developing children's character. Because Sport and Health Physical Education does not develop in terms of intellectual and psychomotor intelligence, but in developing the child's personality it must be achieved. So Physical Education, Sports and Health have a role in shaping children in all aspects, namely Cognitive, Affective and Psychomotor aspects. Individuals who have a strong personality, good character, and noble character can be taken from the value of Physical Education.

Related to character education which is integrated through physical education, traditional games are one of the real manifestations to make it happen. Traditional games are the result of local cultural processes that are still embedded with local wisdom values. In line with opinion [1], Local wisdom is basically the good values of local culture and has received recognition by the majority of the community about its goodness. In other words, local wisdom is an important investment to give students the skills, abilities and qualities to face the global world without leaving their identity or national identity.

And now, the thematic learning model has become a major issue in the world of education and has been emphasized in the 2013 curriculum at the SD/MI level. However, it must be admitted, the implementation still seems overlapping. The internalization of local wisdom values that should be owned by the nation's children is still partial. This is because the thematic learning models that are often used in general are conventional learning models. The learning model tends to be only text books and is focused only in the classroom. Whereas one of the obligations of teachers in teaching is to be able to use a variety of models, strategies, and methods, which can attract students' interest. And make the best possible use of learning 
resources that are around students (local wisdom), as the embodiment of one of the thematic (contextual) characteristics. Local wisdom itself is the root of national culture in which the values contained in it are full of the teachings of goodness. With the elimination of local wisdom results in the loss of the moral and identity-forming joints of the nation's children.

In line with opinion Elisa [2] stated, "Traditional games here are children's games from simple materials according to cultural aspects in people's lives". Traditional games are quite familiar with folk games which aim as entertainment and at the same time maintain social relations. In accordance with the understanding of traditional games, each region has its own characteristics of traditional games. However, most of them in Indonesia have traditional games that have similarities. This is because the values contained in traditional games are able to provide characters that reflect the identity of the nation.

Traditional games as a means to develop the potential of children's character. Along with the development of globalization, the local culture that is manifested by traditional games is getting eroded. So it is very necessary efforts to develop the character of children in elementary schools through traditional games that are packaged in the learning of Physical Education, Sports and Health. Therefore, researchers are interested in conducting research by designing a learning model with the title "Basic Motion Learning Model Based on Traditional Sports Games for Children aged 10-12 Years".

\section{Method}

This research and development uses a qualitative and quantitative approach, which is used to describe and explain data in the form of numbers, especially used when measuring the effectiveness of a model being developed. Research on the development of basic movement learning models based on traditional sports games in basic movement learning uses the Research Development (R\&D) development model from Borg and Gall which consists of ten steps to find answers to the problems that have been formulated in Chapter 1, which can be seen from the chart listed. below this:

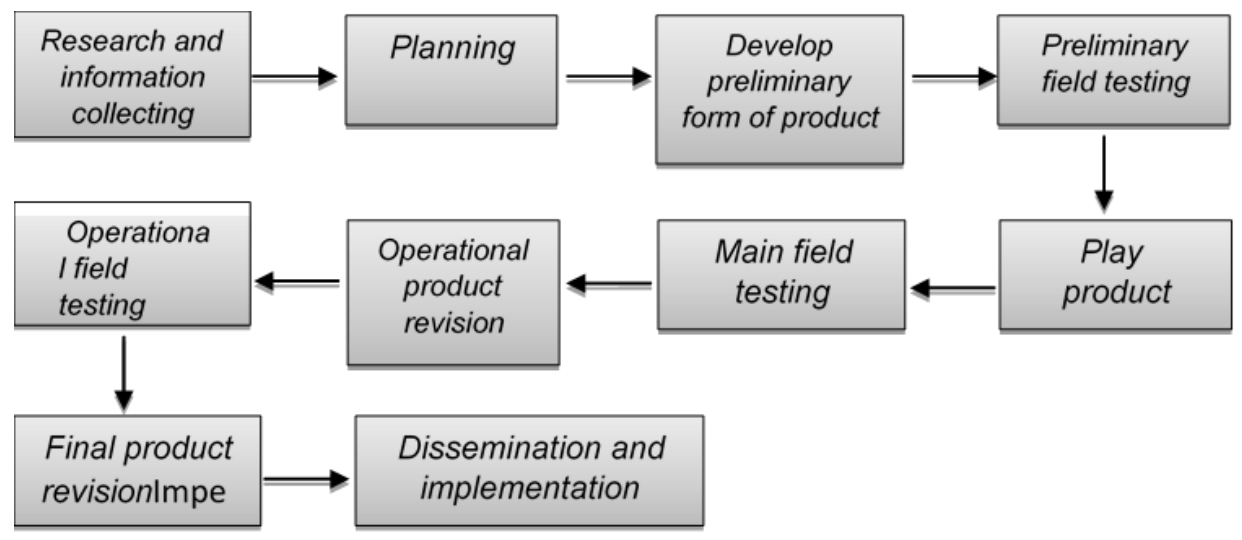

Fig. 1. Borg \& Gall Development Model [3]. 
The place of research is the city of Medan, which is located in North Sumatra.The city of Medan is the capital of the province of North Sumatra, Indonesia. This city is the third largest city in Indonesia. In this study 5 (five) Elementary Schools (SD) which became the subject of research onmbasic motion learning model based on traditional sports games for children aged 10-12 years.

The results of the model development in this study are in the form of a book of basic motion learning models based on traditional sports games for children aged 10-12 years which are interesting, fun and varied and easy to implement. The purpose of developing this model is to produce an effective, efficient and systematic book model for basic movement learning for elementary schools that develops basic movement learning materials. In this chapter, the researcher will also describe the data of informants, units and subjects that are adapted to the research methods carried out by the researchers. Based on the implementation of research activities that have been carried out by researchers in the field, data obtained from the results of (1) Needs analysis or preliminary research containing the results of observations, interviews, questionnaires and literature studies,

In the data collection method in the form of instruments given to: (1) two teachers in the form of interview sheets, (2) conducting a needs analysis with a questionnaire given to 20 research subjects, (3) instruments regarding product feasibility given to experts on product design the development carried out, while the experts/experts/scientists consist of: (a) experts in learning physical education, sports and health (b) experts in traditional sports games, (c) experts in instructional media design. (d) sports physical Education and health Instrument Expert, (4) small group trial of 30 research subjects, (5) large group trial of 120 research subjects, (6) product effectiveness test of 60 subjects consisting of 30 experimental group subjects and 30 control subjects .

After conducting small group trials and large group trials, the next step is to determine the effectiveness of the product development of basic motion learning models based on traditional sports games. The effectiveness test used a research design in the form of a pretest-posttest control group design. The design of this study aims to determine the value of the initial ability of the experimental group, namely the use of basic movement learning models based on traditional sports games for children aged 10-12 years. Significantly higher than the control group's ability value, namely the model used by teachers at school, namely the basic movement exercise learning model from the student textbook. The research sample used in this study amounted to 60 students. The experimental class is 30 students and the control class is 30 students whose implementation is carried out at SD Negeri 064970.

\section{Results and Discussion}

Processing data to test the effectiveness of the basic motion learning model based on traditional sports games using a t-test procedure with the help of IBM SPSS 25 software. Before conducting data analysis, the data obtained must meet one of the analysis prerequisite tests, namely the normality test for the experimental class and control class data. on basic movement skills using the Kolmogorov-Smirnov test at a significant level of $=0.05$. The following are the test results in the experimental group and control group: 
Table 1. Descriptive Statistics of Pretest \& Posttest Results Experimental Group.

\begin{tabular}{ccccc}
\hline $\begin{array}{c}\text { Group } \\
\text { Experiment }\end{array}$ & mean & N & $\begin{array}{c}\text { Std. } \\
\text { Deviation }\end{array}$ & Std. Error Mean \\
\hline Pre-test & 164.10 & 30 & 3.367 & 0.615 \\
Post-test & 172.73 & 30 & 5.558 & 1.015 \\
\hline
\end{tabular}

In table 1 the average results of the basic movement skills test with a sample of 30 students obtained the pretest has a mean of 164.10, and a standard deviation of 3.36. After being given treatment of the basic movement learning model based on traditional sports games, the post test results have a mean of 172.73 and a standard deviation of 5.55. This means that quantitatively there is a difference in the average results of the basic movement skills test before and after being given treatment.

Table 2. Paired Samples Correlation Experimental Group.

\begin{tabular}{lcccc}
\hline \multicolumn{4}{c}{ Paired Samples Correlations } \\
\hline & $\mathrm{N}$ & Correlation & Sig. \\
Pairs 1 & Post Test \& Pre Test & 30 & 0.593 & 0.001 \\
\hline
\end{tabular}

Based on table 2 paired samples correlation, the correlation coefficient of the test scores for basic movement learning outcomes between before (pre test) and after (post test) was given treatment in the form of basic movement learning models based on traditional sports games of 0.593 with a Sig number or $\mathrm{p}$-value $=0.001<0.05$ or significant.

Table 3. Paired Test Results Experimental Group Sample Test.

\begin{tabular}{|c|c|c|c|c|c|c|c|c|c|}
\hline \multicolumn{10}{|c|}{ Paired Samples Test } \\
\hline & & \multicolumn{5}{|c|}{ Paired Differences } & \multirow[t]{3}{*}{$t$} & \multirow[t]{3}{*}{$d f$} & \multirow{3}{*}{$\begin{array}{c}\text { Sig. } \\
(2- \\
\text { taile } \\
\text { d) }\end{array}$} \\
\hline & & \multirow[t]{2}{*}{ mean } & \multirow[t]{2}{*}{$\begin{array}{l}\text { Std. } \\
\text { Deviati } \\
\text { on }\end{array}$} & \multirow{2}{*}{$\begin{array}{c}\text { Std. } \\
\text { Err } \\
\text { or } \\
\text { Mea } \\
n\end{array}$} & \multicolumn{2}{|c|}{$\begin{array}{c}95 \% \text { Confidence } \\
\text { Interval of the } \\
\text { Difference }\end{array}$} & & & \\
\hline & & & & & Lower & Upper & & & \\
\hline Pairs 1 & $\begin{array}{l}\text { Post Test } \\
\text { - Pre Test }\end{array}$ & 8.633 & 4.476 & 0.82 & 6.962 & 10.305 & 10.6 & 29 & $\begin{array}{c}0.00 \\
0\end{array}$ \\
\hline
\end{tabular}

Based on table 3 the results of the paired samples test, the difference in the mean is obtained, namely the difference in the results of the basic movement skill score of 8.63. Based on the table above, the price of tcount $=10.565$ for $=0.05$ and table $=2.045$ it turns out that tcount $>$ ttable, i.e. $10.565>2.045$ and sig value or $p$-value $=0.000>0.05$ with $\mathrm{df}=29$. Thus, $\mathrm{H} 0$ is rejected and $\mathrm{H} 1$ is accepted, which means that there is a difference significant average before (pretest) and after (posttest) given (treatment) the basic motion learning model based on traditional sports games.

The activity carried out in the control group was to apply the model commonly used by the teacher in the field of study at the school, namely by using a basic movement model sourced from the student's sports book called the conventional model. In the control class, the 
treatment time and the number of samples remained the same. From the results of the control class study, it was obtained that the pretest and posttest results were as follows:

Table 4. Test of Paired Samples Statistics Pretest \& Posttest Control Group.

\begin{tabular}{ccccc}
\hline $\begin{array}{c}\text { Group } \\
\text { Control }\end{array}$ & mean & $\mathbf{N}$ & $\begin{array}{c}\text { Std. } \\
\text { Deviation }\end{array}$ & Std. Error Mean \\
& & & & \\
\hline Pre-test & 141.03 & 30 & 11.038 & 2.015 \\
Post-test & 145.37 & 30 & 6.278 & 1.146 \\
\hline
\end{tabular}

Based on table 4 with a sample of 30 people, the mean pre test result is 141.03 and the standard deviation is 11.038. After being given the conventional basic movement learning model, the mean post test result was 145.37 and the standard deviation was 6.278. This means that quantitatively in Table 4, it can be seen that there are differences in the results of the pretest and post-test before and after being given treatment using the conventional model. To determine the correlation between the results of the pre-test and post-test in the control group, the paired samples correlation test was carried out as follows:

Table 5. Test of Paired Samples Correlations Pretest \& Posttest Control Group.

\begin{tabular}{lcccc}
\hline \multicolumn{4}{c}{ Paired Samples Correlations } \\
\hline & & $\mathrm{N}$ & Correlation & Sig. \\
Pairs 1 & Post Test \& Pre Test & 30 & 0.609 & 0.000 \\
\hline
\end{tabular}

Based on table 5, it is obtained that the correlation coefficient of the basic movement learning outcomes between before (pre test) and after being given treatment (post test) conventional basic movement learning model is 0.609 with sig or p-value $=0.000<0.05$ significance. Knowing the results of the significance between the pre test and post test, the paired samples test pretest and posttest were carried out in table 5 below:

Table 6. Paired Samples Test Pretest \& Posttest Control Group.

\begin{tabular}{|c|c|c|c|c|c|c|c|c|c|}
\hline \multicolumn{10}{|c|}{ Paired Samples Test } \\
\hline & & \multicolumn{5}{|c|}{ Paired Differences } & \multirow[t]{3}{*}{$t$} & \multirow[t]{3}{*}{$d f$} & \multirow{3}{*}{$\begin{array}{l}\text { Sig. } \\
(2- \\
\text { tailed) }\end{array}$} \\
\hline & & \multirow[t]{2}{*}{ mean } & \multirow{2}{*}{$\begin{array}{c}\text { Std. } \\
\text { Devia } \\
\text { tion }\end{array}$} & \multirow{2}{*}{$\begin{array}{l}\text { Std. } \\
\text { Error } \\
\text { Mean }\end{array}$} & \multicolumn{2}{|c|}{$\begin{array}{c}\text { 95\% Confidence Interval } \\
\text { of the Difference }\end{array}$} & & & \\
\hline & & & & & Lower & Upper & & & \\
\hline $\begin{array}{l}\text { Pair } \\
\text { s } 1\end{array}$ & $\begin{array}{l}\text { Post Test } \\
\text { - Pre } \\
\text { Test }\end{array}$ & 4.333 & 8.763 & 1.600 & 1.061 & 7.605 & 2.7 & 29 & 0.011 \\
\hline
\end{tabular}

Based on table 6 the results of the paired samples test, the difference in the mean is obtained, namely the difference in the results of the basic movement skills score of 4.333. Based on the table above, the price of tcount $=2.709$ for $=0.05$ and ttable $=2.045$ it turns out 
that tcount $>$ ttable, i.e. $10.565>2.045$ and sig or $p$-value $=0.000>0.05$ with $\mathrm{df}=29$. Thus, $\mathrm{H} 0$ is rejected and $\mathrm{H} 1$ is accepted, which means that there is a difference significant average before (pretest) and after (posttest) given (treatment) conventional learning model. Before conducting the t-test, the researcher must test the prerequisite analysis, namely the normality test. The following is a summary of the results of the normality test calculations shown in table 7 .

Table 7. Summary of Calculation Results of Normality Test Data for Experimental Groups and Control Groups on Basic Movement Skills.

\begin{tabular}{|c|c|c|c|c|c|c|c|}
\hline \multicolumn{8}{|c|}{ Tests of Normality } \\
\hline & \multirow[b]{2}{*}{ Group } & \multicolumn{3}{|c|}{ Kolmogorov-Smirnova } & \multicolumn{3}{|c|}{ Shapiro-Wilk } \\
\hline & & Statistics & $\mathrm{df}$ & Sig. & Statistics & $\mathrm{df}$ & Sig. \\
\hline $\begin{array}{l}\text { Basic } \\
\text { Motion }\end{array}$ & $\begin{array}{l}\text { Experiment } \\
\text { al Group }\end{array}$ & 0.157 & 30 & 0.058 & .949 & 30 & 0.157 \\
\hline $\begin{array}{l}\text { Learning } \\
\text { Results }\end{array}$ & $\begin{array}{l}\text { Control } \\
\text { Group }\end{array}$ & 0.148 & 30 & 0.092 & .932 & 30 & 0.055 \\
\hline
\end{tabular}

Based on table 6 the test results can be seen in the Kolmogorov-Smirnov column, it is known that the sig value for the experimental group data is 0.058 and the control group data is 0.092. The results of the sig value of the two groups $>(0.05)$ it can be concluded that the overall data of the research group is normally distributed. After fulfilling the analysis prerequisite test, namely the normality test, testing the effectiveness of the application of the basic motion learning model based on traditional sports games using the "t-test" which is summarized in table 8 below:

Table 8. Testing the Effectiveness of the Basic Motion Learning Model Using T-Test.

\begin{tabular}{|c|c|c|c|c|c|c|c|c|c|c|}
\hline \multicolumn{11}{|c|}{ Independent Samples Test } \\
\hline & & \multicolumn{2}{|c|}{$\begin{array}{l}\text { Levene's Test } \\
\text { for Equality of } \\
\text { Variances }\end{array}$} & \multicolumn{7}{|c|}{ t-test for Equality of Means } \\
\hline & & \multirow[t]{2}{*}{$\mathrm{F}$} & \multirow[t]{2}{*}{ Sig. } & \multirow[t]{2}{*}{$\mathrm{T}$} & \multirow[t]{2}{*}{$\begin{array}{l}\text { d } \\
\mathrm{f}\end{array}$} & \multirow[t]{2}{*}{$\begin{array}{l}\text { Sig. } \\
(2- \\
\text { taile } \\
\text { d) }\end{array}$} & \multirow{2}{*}{$\begin{array}{c}\text { Mea } \\
\mathrm{n} \\
\text { Diff } \\
\text { eren } \\
\text { ce }\end{array}$} & \multirow{2}{*}{$\begin{array}{c}\text { Std. } \\
\text { Erro } \\
r \\
\text { Diff } \\
\text { eren } \\
\text { ce }\end{array}$} & \multicolumn{2}{|c|}{$\begin{array}{c}95 \% \\
\text { Confidence } \\
\text { Interval of the } \\
\text { Difference }\end{array}$} \\
\hline & & & & & & & & & $\begin{array}{l}\text { Lo } \\
\text { we } \\
\text { r }\end{array}$ & $\begin{array}{l}\text { Uppe } \\
\mathrm{r}\end{array}$ \\
\hline $\begin{array}{l}\text { Basic } \\
\text { Motion } \\
\text { Learnin }\end{array}$ & $\begin{array}{l}\text { Equal } \\
\text { variances } \\
\text { assumed }\end{array}$ & 0.030 & 0.86 & 17.9 & $\begin{array}{l}5 \\
8\end{array}$ & $\begin{array}{r}0.0 \\
00\end{array}$ & $\begin{array}{r}27.3 \\
67\end{array}$ & $\begin{array}{r}1.53 \\
1\end{array}$ & $\begin{array}{r}24 . \\
30 \\
2\end{array}$ & $\begin{array}{r}30.43 \\
1\end{array}$ \\
\hline $\begin{array}{l}\text { g } \\
\text { Results }\end{array}$ & $\begin{array}{l}\text { Equal } \\
\text { variances } \\
\text { not } \\
\text { assumed }\end{array}$ & & & 17.9 & $\begin{array}{l}57 \\
.1 \\
60\end{array}$ & $\begin{array}{r}0.0 \\
00\end{array}$ & $\begin{array}{r}27.3 \\
67\end{array}$ & $\begin{array}{r}1,53 \\
1\end{array}$ & $\begin{array}{r}24 . \\
3\end{array}$ & 30.4 \\
\hline
\end{tabular}


Based on the table above, table 8, in the column Equal variances assumed and Levene's Test for Equality of Variances obtained a value of $\mathrm{F}=0.030$ with a sig value or $\mathrm{p}$-value $=$ $0.864>0.05$, which means that the population variances of the two groups are the same or homogeneous and meet the requirements for hypothesis testing. . The results of the hypothesis test can be seen in the column Equal variances assumed and t-test for Equality of Means. From this column, the value of $\mathrm{t}=17.877, \mathrm{df}=58(\mathrm{n}-2)$ and $\operatorname{sig}(2$ tailed) or $\mathrm{p}$-value $=0.000<0.05$ or $\mathrm{HO}$ is rejected. Thus the proposed hypothesis is tested by the data so that it can be concluded that the basic movement results of the experimental group using the traditional sports development model are higher or effective than the control group using the conventional model.

This research is a research and development (R\&D) which is the development of a basic motion learning model book based on traditional sports games for children aged 10-12 years which is interesting, fun and varied and easy to implement. The purpose of developing this model is to produce an effective, efficient and systematic book model for basic movement learning for elementary schools that develops basic movement learning materials. The stages of the research carried out through several stages, namely (1) Needs analysis or preliminary research containing the results of observations, interviews, questionnaires and literature studies, (2) Variation development planning which includes product design, (3) Design validation using expert review or expert test, (4) product revision based on the results of expert review, (5) Small group trial, (6) Product revision based on small group trial activity, (7) Product trial in large group, (8) Product revision, (9) Product effectiveness test results and 10) Dissemination of research results. This stage was developed based on the development of Borg \& Gall, the research and development stage used ten stages, namely: (1) Conduct research and collect information (library review, observation of subjects, preparation of report on subject matter) (2) Conduct planning (definition of skills, formulation of objectives, determination of teaching sequences, and small-scale trials) (3) Develop initial product forms ( preparation of teaching materials, preparation of handbooks, and evaluation equipment) (4) Conducting initial field tests (using 6-12 subjects) (5) revising the main product (according to suggestions from the results of initial field tests) (6) Conducting main field trial (with $30-100$ subjects) (7) Revise the product (based on the suggestions and results of the main field trial). (8) Field testing with $40-200$ subjects (9) Final product revision (10) making reports on products in journals,

In line with the research stages above, it was obtained that 1) needs analysis was carried out by interviewing sports teachers and observing students. From the results of interviews with teachers, it is concluded that teachers needbasic movement learning model and analysis of student needs $80.63 \%$ students need a variety of basic motion learning models based on traditional sports games. 2) Based on the needs analysis of teachers and students, the researcher plans to develop a model by collecting information by reviewing literacy and literature review to develop a basic movement model for traditional sports. Results have been obtainedobtained 4 (tribes) are planned to be developed in the form of a sports game model. The tribes are the Mandailing Tribe, the Toba Batak Tribe, the Pakpak, and the Medan Mutual Tribe with easy, medium and difficult model criteria. 3) The initial module/product development stage is to develop 6 traditional sports games divided into 9 (nine) traditional sports game models with easy, medium and difficult categories and to design an initial model that produces 54 basic motion models (locomotor, non-locomotor and manipulative). The product designs developed are a) Zondaag Mandaag Traditional Game Model from Mandailing from easy, medium and difficult categories; b) The Traditional Game Model of PT Ni Gajah, from Batak Toba in the easy, medium and difficult categories. c) The Margala 
Traditional Game Model of the Toba Batak is categorized as easy, medium and difficult. d) The traditional game model of breaking plates from Pakpak is categorized as easy, medium and difficult. e) Traditional Clog Game Models from Medan are categorized as easy, medium and difficult. f) The Marjalengkat Traditional Game Model from the Toba Batak is in the easy, medium and difficult categories. 4) The designed model is validated by experts. Expert validation of the product design development carried out will be validated by five experts/experts/scientists consisting of: (a) Two experts on physical education, sports and health learning materials, namely Dr. Rahma Dewi, M.Pd. and Dr. Amir Supriadi, M.Pd. (b) Two traditional game experts, namely Drs. Suryadi Damanik, M.Pd. and Ramadhan Ginting, S.Pd, MM., M.Pd (c) one media expert, namely Khairil Irfan Lubis, S.Si., M.Pd. e) Traditional Clog Game Models from Medan are categorized as easy, medium and difficult. f) The Marjalengkat Traditional Game Model from the Toba Batak is in the easy, medium and difficult categories. 4) The designed model is validated by experts. Expert validation of the product design development carried out will be validated by five experts/experts/scientists consisting of: (a) Two experts on physical education, sports and health learning materials, namely Dr. Rahma Dewi, M.Pd. and Dr. Amir Supriadi, M.Pd. (b) Two traditional game experts, namely Drs. Suryadi Damanik, M.Pd. and Ramadhan Ginting, S.Pd, MM., M.Pd (c) one media expert, namely Khairil Irfan Lubis, S.Si., M.Pd. e) Traditional Clog Game Models from Medan are categorized as easy, medium and difficult. f) The Marjalengkat Traditional Game Model from the Toba Batak is in the easy, medium and difficult categories. 4) The designed model is validated by experts. Expert validation of the product design development carried out will be validated by five experts/experts/scientists consisting of: (a) Two experts on physical education, sports and health learning materials, namely Dr. Rahma Dewi, M.Pd. and Dr. Amir Supriadi, M.Pd. (b) Two traditional game experts, namely Drs. Suryadi Damanik, M.Pd. and Ramadhan Ginting, S.Pd, MM., M.Pd (c) one media expert, namely Khairil Irfan Lubis, S.Si., M.Pd. 4) The designed model is validated by experts. Expert validation of the product design development carried out will be validated by five experts/experts/scientists consisting of: (a) Two experts on physical education, sports and health learning materials, namely Dr. Rahma Dewi, M.Pd. and Dr. Amir Supriadi, M.Pd. (b) Two traditional game experts, namely Drs. Suryadi Damanik, M.Pd. and Ramadhan Ginting, S.Pd, MM., M.Pd (c) one media expert, namely Khairil Irfan Lubis, S.Si., M.Pd. 4) The designed model is validated by experts. Expert validation of the product design development carried out will be validated by five experts/experts/scientists consisting of: (a) Two experts on physical education, sports and health learning materials, namely Dr. Rahma Dewi, M.Pd. and Dr. Amir Supriadi, M.Pd. (b) Two traditional game experts, namely Drs. Suryadi Damanik, M.Pd. and Ramadhan Ginting, S.Pd, MM., M.Pd (c) one media expert, namely Khairil Irfan Lubis, S.Si., M.Pd.

The results of the recapitulation of the average learning material experts of the Basic Motion Learning Model Based on Traditional Sports Games for Children aged 10-12 Years are overall accepted with the average presentation of the overall model, namely (a) Zondaag Mandaag Traditional Game from Mandailing, (b) Pat Traditional Game Ni Gajah, from the Toba Batak, (c) the traditional game of Margala from the Toba Batak, (d) the traditional game of breaking plates from the Pakpak, (e) the traditional game of clogs from Medan, (f) the traditional game of Marjalengkat from the Toba Batak for a total of $78 \%$. The assessment is assessed with indicators of $79 \%$ of objectives, $78 \%$ of implementation instructions, $77 \%$ of implementation, $78 \%$ of Security, and $78 \%$ of Attractiveness. From these results, it was also found that 5 models were not accepted, namely Margala A3, Clog C3, Marjaleangkat B2, Marjalekat C1 and Marjalekat C3. A total of 49 models were accepted from 54 models 
developed. The whole model that was validated by validators 1 and 2 was accepted and supported by several entries that were already in 5) revised to improve the quality of the model.

The average recapitulation of Traditional Sports Game Experts on the Basic Motion Learning Model Based on Traditional Sports Games for Children aged 10-12 Years is generally accepted with the overall average presentation of the model, namely (a) Zondaag Mandaag Traditional Games from Mandailing, (b) Traditional Games Pat Ni Gajah, from the Toba Batak, (c) the traditional game of Margala from the Toba Batak, (d) the traditional game of breaking plates from the Pakpak, (e) the traditional game of clogs from Medan, (f) the traditional game of Marjalengkat from the Toba Batak 78\%. The assessment indicators are based on $78 \%$ of objectives, $79 \%$ of implementation guidelines, $78 \%$ of implementation, $75 \%$ of Security, and $78 \%$ of attractiveness. From these results, it was also found that 5 models were not accepted, namely Margala A3, Clog C3, Marjalengkat B2, Marjaleangkat C1 and Marjaleangkat C3. A total of 49 models were accepted from 54 models developed. All models validated by traditional game experts 1 and 2 were accepted for development. To improve the quality of development there are several suggestions that have been 6) revised.

The average recapitulation of media experts on the Basic Motion Learning Model Based on Traditional Sports Games for Children aged 10-12 Years is generally accepted with the average presentation of the entire model, namely (a) Zondaag Mandaag Traditional Game from Mandailing, (b) Pat Ni Traditional Game Elephants, from the Toba Batak, (c) the traditional game of Margala from the Toba Batak, (d) the traditional game of breaking plates from the Pakpak, (e) the traditional game of clogs from Medan, (f) the traditional game of Marjalengkat from the Toba Batak as much as $75 \%$. Assessment indicators are seen fromclaritybook visualization $81 \%$,attractivenessmaterial $75 \%$,suitabilitybook writing $69 \%$, andaccuracy $75 \%$ model image. From these results it can be concluded that the basic motion learning model based on traditional sports games for children aged 10-12 years is accepted to be developed with several revised improvements.

The next research stage is 7) small group trial. This stage is carried out by completing improvements from the input provided by PJOK learning material experts, traditional sports game experts and media experts. The small group test was carried out by field testing. Field trials for small groups with research subjects $(n=30)$ students aged 10-12 years by observing the implementation of the developed model. The research subject is located in The results of the small group trial carried out at SD Negeri 064970. data recapitulation of the small group trial results on the development of basic motion learning models based on traditional sports games obtained an average of $78.33 \%$, so the product is in the accepted category. In addition to looking at the use of basic motion learning models based on traditional sports games for children aged 10-12 years, the researchers also measured student activity. Calculations in the recapitulation of student activity questionnaires can be seen that most students are happy with the implementation of basic motion learning models based on traditional sports games, namely $66.7 \%$ happy and $33.3 \%$ very happy. After conducting small group trials and revisions, then proceed with large group trials.

In stage 8) large group trial. Researchers used 120 subjects. Large-scale subjects were spread in 4 locations, namely 30 subjects in SD Negeri 060911 Masrukiah study teachers, 30 subjects at SD Negeri 066054 study teachers Surdi Saragih, S.Pd, 30 subjects at SD Negeri 067980 study teachers Lisraida Sinaga, S.Pd and 30 subject SD Negeri 064978 teacher of study Sarwo Edi S.Pd. the average percentage of the results of the large group trial of 120 people was $77.91 \%$ so that overall the products developed were in the accepted category and underwent several revisions based on notes in the field. It can be seen that the developed 
model prioritizes the objectives of the learning implementation, so the implementation in the field does not experience significant obstacles. In addition to seeing the feasibility of the basic movement learning model based on traditional sports games for children aged 10-12 years, the researchers also measured the activities of large group students. In the recapitulation of the student activity questionnaire, it can be seen that most of the students were happy with the implementation of the basic motion learning model based on traditional sports games, namely $75 \%$ happy and $25 \%$ very happy.

The next step that can be taken by researchers is to do 9) effectiveness tests. The effectiveness test used a research design in the form of a pretest-posttest control group design. The research sample used in this study amounted to 60 students. Experiment class 30 students and control class 30 students whose implementation was carried out at SD Negeri 064970. The effectiveness of the basic movement learning model based on traditional sports games using a t-test procedure assisted by IBM SPSS 25 software. students obtained the pretest has a mean of 164.10 and a standard deviation of 3.36. After being given treatment of the basic movement learning model based on traditional sports games, the post test results have a mean of 172.73 and a standard deviation of 5.55. This means that quantitatively there is a difference in the average results of the basic movement skills test before and after being given treatment. The average results of the control class with a sample of 30 people obtained the mean pre test result of 141.03 and standard deviation of 11.038. After being given the conventional basic movement learning model, the mean post test result was 145.37 and the standard deviation was 6.278. This means that quantitatively there is a difference in the results of the pre test and post test before and after being given treatment using the conventional model. To test the effectiveness of the model using the t-test by meeting the prerequisite tests for normality and homogeneity. The results of the normality test are seen from the Kolmogorov-Smirnov value, it is known that the sig.i value for the experimental group data is 0,058 and the control group data is 0.092 . The results of the sig value of the two groups $>(0.05)$ it can be concluded that the overall data of the research group is normally distributed. Homogeneity seen by the value of Equal variances assumed and Levene's Test for Equality of Variances obtained F value = 0.030 with sig value or $\mathrm{p}$-value $=0.864>0.05$, which means that the population variance of the two groups is the same or homogeneous and meets the requirements for hypothesis testing. From the results of data testing, it was obtained that Equal variances assumed and t-test for Equality of Means with a value of $\mathrm{t}=17.877$, $\mathrm{df}=58(\mathrm{n}-2)$ and sig (2 tailed) or $\mathrm{p}$-value $=$ $0.000<0.05$ or $\mathrm{H} 0$ was rejected.

This research shows that in general the results of the development of basic movement learning models based on traditional sports games can be carried out by children aged 10-12 years. In line with the opinion of the learning model can be interpreted as a plan or pattern used in compiling the curriculum, arranging learning materials and giving instructions to the teacher in the learning process. Elias M. Award \& Hassan M Ghaziri [4]stated that "A models is a representation of a real of planned system." The purpose of this statement is the model as a representation of a planned system reality. The learning model is a plan that is used to design.Development resultsThe basic movement learning model based on traditional sports games can be implemented by children aged 10-12 years in observing the use of models and student activities. It was found that the learning process of sports is increasingly favored by students both in terms of cognitive, affective and psychomotor in line with the opinion of Thomas, et al [5] classifies learning outcomes into three domains, namely (1) the cognitive domain, (2) the affective domain, and (3) the psychomotor domain. The cognitive domain is a child's mastery of the basic movements of sports and the knowledge that has been obtained through a learning process related to thinking, remembering, and problem solving activities 
that refer to information stored in the mind through traditional sports games. The affective domain includes learning outcomes related to attitudes towards certain values, morals, and norms that are conveyed to the model, namely aspects of courage, confidence, enthusiasm, hard work and skill. Meanwhile, the psychomotor domain relates to the skills possessed to develop or create something that appears in student performance activities at every step of traditional sports games. Based on these three considerations, the researchers developed a basic movement learning model based on traditional sports games that can be carried out by children aged 10-12 years to reduce student boredom when learning takes place.

\section{Conclusion}

Based on the results and processing of research data and discussion, the research can be concluded as follows: The basic movement learning model (locomotor, non-locomotor and manipulative) based on traditional sports games for children aged 10-12 years is declared acceptable based on (a) two PJOK learning material experts The results obtained are 78\%, (b) experts on traditional sports games, the results are $78 \%$, (c) learning media experts, the results are $75 \%$. Overall, the average validation of the overall product assessment is $75 \%$, so the conclusion is that the model is accepted.From these results also found 5 models that are not accepted, namely Margala A3, Clogs C3, Marjalengkat B2, Marjalengkat C1 and Marjalengkat C3. A total of 49 models were accepted from 54 models developed. The development of basic movement learning models (locomotor, non-locomotor and manipulative) based on traditional sports games for children aged 10-12 years is effective for improving basic movement learning outcomes. Based on the results of the Equal variances assumed and Levene's Test for Equality of Variances test results, $F=0.030$ with a sig value or p-value $=0.864>0.05$, which means that the population variances of the two groups are the same or homogeneous. The results of the Equal variances assumed hypothesis test and t-test for Equality of Means obtained a value of $\mathrm{t}=17.877$, $\mathrm{df}=58$ and sig ( 2 tailed) or $\mathrm{p}$-value $=$ $0.000<0.05$ or $\mathrm{H} 0$ is rejected. The results of basic locomotor, non-locomotor and manipulative movements based on traditional sports games in children aged 10-12 years in the experimental group were higher or effective than the control group.

\section{References}

[1] Wafiqni N, SN. Thematic Learning Model. J Islamic Basic Educ. 2018; XI(1):119-132.

[2] Kokali YES. The Effectiveness of Gobag Sodor Traditional Game To Reduce Aggressive Behavior In Second Grade Elementary School Students. Semarang: Universitas Katolik Soegijapranata; 2017.

[3] Borg WR, Gall MD. Educational Research: An Introduction. $4^{\text {th }}$ Edition. New York: Longman Inc; 1983.

[4] Awad EM, Ghaziri HM. Knowledge Management. $2^{\text {nd }}$ Edition. Virginia: International Technology Group; 2010.

[5] Thomas KT, Lee AM, Thomas JR. Physical Education Methods for Elementary Teachers. $3^{\text {rd }}$ Edition. United States of America: Human Kinetics; 2008. 